\title{
Banks as firms' blockholders: a study in Spain
}

\author{
Josep A. Tribó Ginéa,* and María José Casasola Martínez ${ }^{\mathrm{b}}$ \\ ${ }^{a}$ Department of Business, Universidad Carlos III, C/Madrid 126, \\ 28903 Getafe, Spain \\ ${ }^{\mathrm{b}}$ Department of Engineering, Universidad Carlos III, C/Madrid 126, \\ 28903 Getafe, Spain
}

This article analyses how a firm's returns are affected when a bank becomes a large blockholder. We investigate this issue by taking into consideration the types of blockholders that build coalitions with banks in order to control a firm. We find that the effect on a firm's returns is negative when a bank buys the largest stake and forms coalitions with other banks. However, this negative effect does not apply in other situations. We underscore our theoretical conjectures based on an empirical analysis of a panel dataset comprising a representative sample of listed and unlisted Spanish firms over the period 1996 to 2000.

\section{Introduction}

Recently, the literature on ownership structure has broadened its main focus by considering not only agency problems between managers and shareholders, but also those potential conflicts between large shareholders and minority shareholders (Zwiebel, 1995; Pagano and Röell, 1998; Gomes and Novaes, 2005). Large shareholders want to gain control in order to enforce decisions that would give them some private benefits of control at the expense of minority shareholders. To model this feature, the literature on this subject departs from a concept of ownership concentration that is based on one major blockholder and a diverse group of small shareholders (Demsetz and Lehn, 1985; Shleifer and Vishny, 1986; Berglöf, 1990), to another that incorporates different large blockholders in a firm's ownership structure. This latter approach allows us to address strategic issues, such as the formation of coalitions between the main blockholders and their effects on a firm's policy (Bennedsen and
Wolfenzon, 2000; Morck, 2000; Bloch and Hege, 2002; Gomes and Novaes, 2005). Our article relies on this literature and studies the effect on a firm's returns when a bank becomes one of the largest shareholders of a firm that has other blockholders. Our basic claim is that this effect is very much related to the characteristics (whether or not they are banks) of the blockholders with whom banks can form coalitions in order to achieve the effective control of a firm.

The literature has not yet reached a consensus on the effect of banks' ownership on a firm's returns. Some papers find a negative effect (Hellwig, 1998; Morck et al., 2000; Goergen et al., 2005), while others, relying on the monitoring expertise of banks, describe a positive relationship (Cable, 1985; Kaplan and Minton, 1994; Boehmer, 2000; Gorton and Schmid, 2000). Finally, there is a strand of the literature that does not find a clear-cut relationship (Prowse, 1992; Zoido, 1998 ${ }^{1}$ ). Hence, the debate remains open and there is no conclusive evidence as to what the real effect could be.

\footnotetext{
*Corresponding author. E-mail: joatribo@emp.uc3m.es

${ }^{1}$ Zoido (1998) finds no relationship using accounting measures, but finds a positive relationship using market data.
} 
This article contributes to the debate by focusing on the nature of the largest blockholders (individuals, corporations, families, banks) that control a firm. The aim is to find out whether the types of coalitions that banks may form with other specific blockholders has an effect on a firm's profitability. Our conjecture is that once a bank has become one of the largest blockholders and is compelled to form coalitions with other blockholders to control a firm, it has more expropriating incentives if the accompanying blockholders are banks, as opposed to other types of blockholders.

To test our theoretical contention, we carry out an empirical investigation on a sample of Spanish firms for the period 1996 to 2000. This sample is composed mainly of nonlisted firms; however, we also perform a separate analysis for listed firms. Making use of accounting data as well as market data, we find that the results confirm in essence our main conjecture: once a bank acquires the status of main blockholder, it produces a negative impact on a firm's returns when it colludes with other banks. However, this is not true in other situations.

The remainder of the article is organized as follows: Section II develops the theoretical underpinnings; in Section III, some descriptive analysis is shown and Section IV displays the econometric study. An analysis of robustness is carried out in Section V. The article ends with some final remarks.

\section{Theoretical Underpinnings}

\section{The role of banks as blockholders}

Banks (henceforth, we use the word banks to refer to both banks and savings and loans institutions) are special as blockholders because they have a significant influence on firms in which they have a holding that far outweighs the magnitude of their stake. Santos and Rumble (2006) report that $25 \%$ of their sample of 403 US firms from the Standard \& Poor's (S\&P) 500 have a bank nominee on their board although the Glass-Steagall Act restricts banks from buying stocks in firms. ${ }^{2}$ For Japan, Hoshi and Kashyap (2001) report that $52 \%$ of the 761 firms listed on the first section of the Tokyo Stock Exchange, in 1992, had a bank nominee on their board. Edwards and Fischer (1994) find that $75 \%$ of the 100 largest, publicly traded firms in Germany had a bank nominee on the board in the previous
20 years. However, the percentage of banks' shareholdings compared with their overall assets is just $4.6 \%$ in Japan and 4.8\% in Germany (Santos, 1998). Hence, banks have a presence on the boards in firms even though they do not hold commensurate shareholdings. This influence can be explained in terms of the different channels through which banks accumulate power.

The first channel that banks may use to exercise their power is the lending channel. Shareholder banks tend to be lenders as well (Kroszner and Strahan, 2001; La Porta et al., 2003). Undoubtedly, by controlling the credit channel in firms where they have a stake, blockholder banks can boost their influence given that they have the ability to block loan renewals when firms need them most (Gorton and Winton, 2003). They gain more muscle with which to influence a firm's decisions in line with their own interests (e.g. forcing a firm to borrow money at higher than market rates). González (2004) shows that for a sample composed of 24 Organization for Economic Co-operation and Development (OECD) countries, banks may use their shareholder position in nonfinancial firms as a mechanism to extract benefits from the lending relationship that they usually maintain with firms in which they take equity. Santos and Rumble (2006) show for a sample of US firms that this lending relationship is even more important than voting power in explaining the presence of banks on the boards.

Second, banks may hold proxies for minority shareholders with whom they are closely linked through their voting rights (Berglöf, 1990; Rajan and Zingales, 2003). For example, as reported by Gorton and Schmid (2000), in Germany investors generally deposit their stock with a bank and give the bank permission to vote on their behalf (proxy voting). As a consequence of this delegation of power, banks generally sit on the board and may exert their influence in the firm as reference blockholders.

Finally, banks may resort to cross-shareholdings and pyramidal schemes so as to augment their power in excess of that corresponding to their stake. Degryse and de Jong (2006) provide evidence of cross-shareholdings for the Netherlands, while Becht and Boehmer (2002) show this aspect for Germany. Also, banks take part in pyramidal schemes which give them firms' control even though they have a small individual stake. La Porta et al. (1999) show the existence of pyramidal schemes in Spain that are larger than the average for a sample composed of 27 different countries. Finally, Gorton and

${ }^{2}$ The Gramm-Leach-Bliley Financial Services Modernization Act of 1999 has loosened restrictions imposed by the GlassSteagall Act of 1933 on bank ownership of equity in nonfinancial firms. 
Winton (2003) explain how banks use stock pyramids to concentrate their voting powers. ${ }^{3}$

Within this scenario, the rents accruing to banks due to control are much higher than those derived from their stakes. This situation provides controlling blockholders (banks) all the more incentive to expropriate minority shareholders; they have sufficient power to force expropriation in order to further their own interests, while only internalizing a small proportion of the expropriating costs as a consequence of their low stake.

\section{The presence of other blockholders}

We argue that banks' stockholdings may stimulate expropriating strategies thereby damaging a firm's returns. However, the effective implementation of such a strategy, when a bank does not exercise effective control of a firm, will be contingent on the type of accompanying blockholder that a bank has to contend with. Within this scheme, we may find a whole set of results of the presence of banks on a firm's returns given the variety of possible accompanying shareholders colluding with banks.

The literature on this issue confirms this prediction. Several studies, such as Cable (1985), Gorton and Schmid (2000), for Germany; and Hoshi et al. (1990), for Japan, show the existence of a positive relationship between banks' ownership and firm returns. They emphasize the positive view of banks as stable shareholders that are specialists in monitoring. Other works do not find a significant relationship (Zoido, 1998, for Spain; Edwards and Nibler, 2000 as well as Chirinko and Elston, 2006, for Germany; and Prowse, 1992, ${ }^{4}$ for Japan). Finally, other papers, such as Banerjee et al. (1997) for holding companies in France; Morck et al. (2000), ${ }^{5}$ show the existence of a negative relationship due to the strong power of banks.

Our contention is that it is possible to reconcile the previous results if we incorporate into the analysis the types of coalitions that banks form with other blockholders in order to control a firm. We argue that homogeneous coalitions between banks expropriate more and, consequently, have a particularly negative effect on a firm's returns. However, this may not be the case when a noncontrolling blockholder bank colludes with nonbanks to control a firm. ${ }^{6}$ We base this statement on the following factors.

First, banks tend to follow more homogeneous patterns in their investment decisions in comparison with other types of blockholders. According to Saunders and Walter (1994), German banks are risk-averse investors who invest mainly in large firms. Winton (2001) connects this homogeneous investment pattern as responses to banks' liquidity considerations given their needs to meet unexpected withdrawals or loan takedowns. These potential liquidity needs also explain banks' investment in their own conservative sector (Crespi-Cladera and Garcia-Cestona, 2002 for Spain). Thus, the homogeneity in investment patterns among banks will lead to the convergence of interests and will facilitate collusion to expropriate the minority. We define this as the homogeneous effect.

Second, banks can overcome potential disagreements that may hinder their collusive agreement because they have access to a wide range of perquisites to choose from in order to materialize their collusive agreements aimed at expropriating. This is particularly true in European countries where universal banks offer a wide range of services apart from credit. These different services, ranging from insurance to consulting and underwriting, define a set of channels that facilitate not only the direct expropriation of firms but also the co-operation among blockholder banks in order to extract rents from the firm.

The previous arguments suggest that when banks form coalitions among themselves (homogeneous controlling coalitions); they reinforce their expropriating strategies, resulting in a particularly negative effect on a firm's returns. Conversely, when a bank forms a controlling coalition with a nonbank, the process of decision-making is influenced by a bargaining effect. These are the potential difficulties that a group of blockholders may face when agreeing

\footnotetext{
${ }^{3}$ An additional issue is the presence of dual class-shares that, if controlled by banks, would stimulate to a larger extent these expropriating problems. However, this is not a major problem in Spain given that Faccio and Lang (2002) report that in 1997 only $0.16 \%$ of the 632 listed Spanish firms in their sample have a dual-class equity structure. For nonlisted firms, this proportion should even be lower given that the lack of liquidity for shares facilitates the control of the largest shareholders without using such type of shares.

${ }^{4}$ This author finds a positive relationship for independent Japanese firms, but this is not the case for firms that are members of corporate groups (keiretsu).

${ }^{5}$ These authors find a negative relationship in a sample of Japanese banks, when their stake in their partially-owned firms is moderated.

${ }^{6}$ Applied to another type of blockholder (families), Maury and Pajuste (2005) analyse a sample of Finnish listed firms and they find that the coalition of two families has a negative effect on a firm's value, while the opposite is true when the coalition is with a nonfamily owner (generally a financial institution).
} 
on expropriating the minority, particularly when the number of banking relationships, whether as shareholders or lenders (Han et al., 2008), increases. ${ }^{7}$

Finally, and complementary to the negative effect on a firm's returns linked to minority expropriation actions by a homogeneous coalition of banks, we expect a second effect: the reduction in the stake of the controlling blockholders - to minimize expropriating costs. Also, we expect such a reduction in the stake of other noncontrolling blockholders that are less interested in investing in a firm where the largest blockholders expropriate from the remaining ones. Then, our first hypothesis reads as follows:

Hypothesis 1: There is a negative impact on a firm's returns, as well as on the stake of the controlling blockholders and on that of all blockholders, when a bank acquires one of the largest stakes in a firm that has other banks as controlling blockholders.

Then, if we focus on heterogeneous blockholder structures composed of banks and nonbanks, we expect different results contingent on the type of the largest blockholders. In particular, structures with a bank as the leading shareholder should generate more intensive expropriating policies. A bank as a leading shareholder has strong bargaining power and can impose expropriating actions by ignoring contrary opinions from other nonbank blockholders in this heterogeneous structure. We define this as the leading effect. Boehmer (2000) making use of a sample of German bidder firms shows that takeovers only increase the value of acquiring firms that have banks as blockholders, if banks are not the largest blockholders and the control is counterbalanced by another type of shareholder.

Additionally, the aforementioned negative impact on a firm's returns would also be followed by a reduction in the stake of the controlling coalition as well as in the stakes of those blockholders that do not belong to that coalition as a way of minimizing expropriation costs. Hence, our second hypothesis states as follows:

Hypothesis 2: When a bank buys a significant stake in a firm that does not have other banks with large stakes, there is more expropriation when it acquires the largest stake as opposed to the second-largest one. This means that the effect on a firm's returns and on the stake of the largest blockholders is more negative in the former than in the latter case.

\section{Database and Descriptive Analysis}

\section{The Spanish banking sector}

The banking sector is regulated in Spain. However, Spanish financial institutions have full autonomy to set interest rates for their loans and deposits, and they are also free to decide on their commercial policy in terms of the number of branches and locations. Three main types of institutions compete in this sector: banks, Savings and Loans (S\&L) and cooperatives. However, the first two types are the most important as they account for $95 \%$ of the loan and deposit markets (Crespi-Cladera et al., 2004). Of these two types of institutions, saving and loans have shown the largest increase in market share at the expense of banks. In particular, the market share of savings banks was $39.8 \%$ of the deposit sector, and $33.9 \%$ of the loans market, in 1990; however, by December 2002 , the figures were $46.9 \%$ and $44.1 \%$, respectively (Crespí-Cladera et al., 2004). Such an increase in market share can be explained by the particular corporate governance of S\&L whose objective function also incorporates stakeholders' interests (Granero and Redondo, 2005).

The decline in interest rates, as a result of the convergence to the EMU and deregulation (Kumbhakar and Lozano, 2004), has resulted in a decline in the spread between lending and borrowing rate, which has put pressure on banks to converge and improve their efficiency (Lozano, 1998) and create value (Guzmán and Reverte, 2008). In 1990, this spread was 5.5 percentage points, whereas by the year 2000, the spread was only 3 percentage points. This process of convergence facilitated the integration of different services within a single bank. The end result was that financial institutions were endowed with sufficient muscle to acquire significant stakes in industrial firms and influence decisions through their presence on boards. Hence, the Spanish case is a natural framework for studying the possible expropriating actions of banks as blockholders.

\section{The data}

We carry out our empirical analysis making use of a sample of Spanish firms for the period 1996 to 2000. This sample is extracted from the Sistema de Análisis de Balances de Empresas Españolas (SABE) database. This database is compiled by Bureau Van Dijk and provides annual information on balance sheets, income statements and other complementary

\footnotetext{
${ }^{7}$ It may also be the case that a blockholder bank has a stake in another. Such a possibility may hinder the bargaining effect, while stimulating banks' expropriating intentions in the case of the presence of different banks in a firm's ownership regardless of their number.
} 
information, such as a firm's ownership. We focus on nonfinancial firms that provide information on ownership. We apply some filters to rule out firms with inconsistencies in their balance sheets. ${ }^{8}$ The final outcome is an unbalanced panel data of 4400 firms, the majority of which are nonlisted (133 firms that represent $3 \%$ of the sample are listed), with 12629 observations for the period 1996 to 2000 . Once we impose the condition that firms should provide information in all variables that define specifications (1) and (2) to be contrasted, and that the stake of the largest blockholder is lower than $50 \%$, the sample decreases to 1330 firms and 4083 observations. ${ }^{9}$ Small and Medium-Sized Enterprises (SMEs) (less than 250 employees) account for over $90 \%$ of our sample; this is comparable with the proportion $(84 \%)$ for the overall economy. Moreover, the distribution of economic sectors in our sample closely matches those of the Spanish economy. Hence, we are confident that our sample is representative of Spanish firms.

\section{Descriptive evidence}

In this section, we show the main characteristics of the ownership structure of Spanish firms and the role that banks play in those structures. The variables used throughout the study are defined in Table 1.

Table 2 shows that the average stake of the two largest shareholders is $53.80 \%$. Hence, it seems reasonable to focus on the two main shareholders as a firm's controlling blockholders (henceforth, we denote the two largest blockholders as controlling blockholders). We also consider the stake of all blockholders, whose mean stake is $70.91 \%$. We define blockholders as those shareholders with a stake of at least $5 \%$. Concerning the variables of performance, the mean Return On Assets (ROA) is 1.09 , while the mean Tobin_Q is 1.28 , which indicates that the mean firm of the sample is not one of growth.

Next, we present evidence of different factors that influence banks' ownership as well as the types of coalitions that banks form with other blockholders in order to control a firm.

Table 3 shows that banks tend to form coalitions with other banks rather than with nonbanks: a bank emerges as the largest blockholder with a probability of $22.75 \%$ when the second-largest shareholder is also a bank and with a probability of $1.15 \%$ when it is not.
Also, these probabilities are $20.8 \%$ versus $1.04 \%$ when we focus on the presence of banks as the second-largest blockholders. This means that there is a higher probability that one of the largest shareholders is a bank when the other is also a bank, instead of another type of blockholder. Also, from Table 3, we can extract the conclusion that there is a lower probability of finding banks that hold stakes after a period such that DEBT_ASSETS has a larger value than the mean of the sector for the corresponding year. This result may be consistent with the idea that banks are eager to expropriate and consequently avoid those situations where the slack in resources to expropriate from are lower (i.e. when debt level is large, according to the free cash-flow theory; Jensen, 1986).

Next, we focus on the consequences of bank ownership on blockholders' stake and on a firm's returns. This analysis is conducted in the following section.

\section{Econometric Estimations}

\section{Methodology}

In order to investigate whether banks holding the largest stakes expropriate minority shareholders, we focus on the changes in blockholders' stake as well as on the returns of those firms with bank stakeholdings. Our strategy is to estimate two different models: one, on a firm's returns and the other on the main shareholders' stake as well as on the overall blockholders' stake. We recognize the potential endogeneity between both variables by allowing each dependent variable in one equation to enter as an independent variable in the other one. This is shown to be the case in studies such as Demsetz and Villalonga (2001).

We conduct a longitudinal study of the effects of changes in a firm's controlling blockholders that are linked to banks. In particular, we focus on these effects on a firm's ownership and returns. We identify five possible changes in those controlling coalitions that involve banks. They are described by five different dummy variables ('transitional dummies') that are defined in Table 1 (NBNB_BNB; NBNB_NBB; NBB_BB; BNB_BB; NBB_BNB). ${ }^{10}$ By using these variables, we capture the effect of

\footnotetext{
${ }^{8}$ We have ruled out those firms with negative values in positive-defined accounts (sales, debt, intangibles). Also, we have eliminated from our sample those firms where the sum total of the stakes of the controlling blockholders is larger than $100 \%$.

${ }^{9}$ We impose that the stake of the largest blockholder should be lower than $50 \%$ for allowing the formation of coalitions of more than one blockholder. Otherwise, the largest blockholder would have had the effective control of the firm, making the analysis of the effect of the other blockholders on performance irrelevant.

${ }^{10}$ We have not included transitional dummy NBNB_BB, because there are no observations in our sample of a firm where two banks simultaneously become the two largest blockholders in a firm that did not previously have banks as blockholders.
} 


\begin{tabular}{|c|c|}
\hline Variable & Definition \\
\hline \multicolumn{2}{|c|}{ Bank-related variables } \\
\hline BANK1 & A dummy that is equal to 1 if the main shareholder is a bank and 0 otherwise. \\
\hline BANK2 & A dummy that is equal to 1 if the second-largest shareholder is a bank and 0 otherwise. \\
\hline $\mathrm{BB}$ & A dummy that is equal to 1 if the two largest shareholders are banks and 0 otherwise. \\
\hline $\mathrm{BNB}$ & $\begin{array}{l}\text { A dummy that is equal to } 1 \text { if the main shareholder is a bank, but the second largest is not a } \\
\text { bank, and } 0 \text { otherwise. }\end{array}$ \\
\hline NBB & $\begin{array}{l}\text { A dummy that is equal to } 1 \text { if the second-largest shareholder is a bank but the largest one is } \\
\text { not a bank, and } 0 \text { otherwise. }\end{array}$ \\
\hline NBNB & A dummy that is equal to 1 if the two main shareholders are not banks and 0 otherwise. \\
\hline NBNB_ BNB & $\begin{array}{l}\text { A dummy that is equal to } 1 \text { when two conditions are satisfied: in period } t-1 \text { none of the two } \\
\text { largest shareholders are banks }(\mathrm{NBNB}=1) \text {; and in period } t \text { the largest shareholder is a bank } \\
\text { but the second-largest one is not }(\mathrm{BNB}=1) \text {. It is equal to } 0 \text { in the rest of the cases. }\end{array}$ \\
\hline NBNB_ NBB & $\begin{array}{l}\text { It is equal to } 1 \text { when two conditions are satisfied: in period } t-1 \text { none of the two largest } \\
\text { shareholders are banks }(\mathrm{NBNB}=1) \text {; and in period } t \text { the second-largest shareholder is a } \\
\text { bank but the largest one is not a bank }(\mathrm{NBB}=1) \text {. It is equal to } 0 \text { in the rest of the cases. }\end{array}$ \\
\hline NBB_BB & $\begin{array}{l}\text { A dummy that is equal to } 1 \text { when two conditions are satisfied: in period } t-1 \text { the } \\
\text { second-largest shareholder is a bank but the largest one is not a bank }(\mathrm{NBB}=1) \text {; and in } \\
\text { period } t \text { the two largest shareholders are banks }(\mathrm{BB}=1) \text {. It is equal to } 0 \text { in the rest of the } \\
\text { cases. }\end{array}$ \\
\hline BNB_BB & $\begin{array}{l}\text { A dummy that is equal to } 1 \text { when two conditions are satisfied: in period } t-1 \text {, the largest } \\
\text { shareholder is a bank but the second-largest one is not }(\mathrm{BNB}=1) \text {; and in period } t \text { the two } \\
\text { largest shareholders are banks }(\mathrm{BB}=1) \text {. It is equal to } 0 \text { in the rest of the cases. }\end{array}$ \\
\hline NBB_BNB & $\begin{array}{l}\text { A dummy that is equal to } 1 \text { when two conditions are satisfied: in period } t-1 \text {, the } \\
\text { second-largest shareholder is a bank but the largest one is not a bank }(\mathrm{NBB}=1) \text {; and in } \\
\text { period } t \text { the largest is a bank but the second-largest one is not }(\mathrm{BNB}=1) \text {. It is equal to } 0 \text { in } \\
\text { the rest of the cases. }\end{array}$ \\
\hline NLNBNB_BNB & $\begin{array}{l}\text { The result of multiplying NL times NBNB_BNB, where NL is a dummy variable that takes } \\
\text { the value of } 1 \text { when banks as shareholders do not have a lender relationship with the firm } \\
\text { and } 0 \text { otherwise. }\end{array}$ \\
\hline \multicolumn{2}{|r|}{ 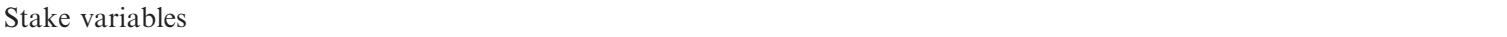 } \\
\hline OWNALL & Combined ownership of those blockholders with a minimum stake of $5 \%$, \\
\hline OWN2 & Measures the ownership stake of the two largest shareholders. \\
\hline \multicolumn{2}{|l|}{ Performance variables } \\
\hline ROA & Ratio of earnings, before interest and taxes to a firm's assets. \\
\hline TOBIN_Q & $\begin{array}{l}\text { It is approached by the market-to-book ratio (the market value of equity to the book value of } \\
\text { equity). }\end{array}$ \\
\hline \multicolumn{2}{|r|}{-1 } \\
\hline LSALES & Firm overall sales on a log scale. \\
\hline AGE & Firm age. \\
\hline $\mathrm{R} \& \mathrm{D}$ & The ratio of $R \& D$ expenses to sales. \\
\hline DEBT_ASSETS & Firm total debt to total assets. \\
\hline
\end{tabular}

Table 2. Descriptive analysis

\begin{tabular}{|c|c|c|c|c|c|}
\hline Variable & Obs. & Mean & Std. & Min & Max \\
\hline \multicolumn{6}{|l|}{ Stake variables } \\
\hline OWNALL & 4083 & 70.915 & 34.794 & 0 & 100 \\
\hline OWN2 & 4083 & 53.802 & 28.957 & 0 & 100 \\
\hline \multicolumn{6}{|c|}{ Performance variables } \\
\hline ROA & 4083 & 1.098 & 0.099 & 0.460 & 2.971 \\
\hline TOBIN_Q & 166 & 1.282 & 4.959 & 0.036 & 42.603 \\
\hline \multicolumn{6}{|l|}{ Control variables } \\
\hline LSALES & 4083 & 14.646 & 1.416 & 6.882 & 21.225 \\
\hline AGE & 4083 & 22.290 & 15.130 & 2 & 77 \\
\hline $\mathrm{R} \& \mathrm{D}$ & 4083 & 0.007 & 0.068 & 0 & 3.115 \\
\hline DEBT_ASSETS & 4083 & 0.184 & 0.172 & 0 & 0.900 \\
\hline
\end{tabular}

Note: See the definition of variables in Table 1. 


\begin{tabular}{|c|c|c|c|}
\hline & $\begin{array}{l}\text { Probability of } \\
\text { BANK } 1=1\end{array}$ & $\begin{array}{l}\text { Probability of } \\
\text { BANK } 2=1 \text { if }\end{array}$ & $\begin{array}{l}\text { Probability of } \\
\text { NBNB }=0\end{array}$ \\
\hline $\begin{array}{l}\mathrm{BANK} 2=1 \\
\mathrm{BANK} 2=0 \\
p \text {-value }^{\mathrm{a}}\end{array}$ & $\begin{array}{r}22.75 \% \\
1.15 \% \\
(0.000)\end{array}$ & & \\
\hline $\begin{array}{l}\mathrm{BANK} 1=1 \\
\mathrm{BANK} 1=0 \\
p \text {-value }^{\mathrm{a}}\end{array}$ & & $\begin{array}{c}20.8 \% \\
1.04 \% \\
(0.000)\end{array}$ & \\
\hline $\begin{array}{l}\mathrm{ROA}_{-} 1=1 \\
\mathrm{ROA}_{-} 1=0 \\
p \text {-value }^{\mathrm{a}}\end{array}$ & $\begin{array}{l}1.492 \% \\
1.351 \% \\
(0.522)\end{array}$ & $\begin{array}{l}1.368 \% \\
1.242 \% \\
(0.552)\end{array}$ & $\begin{array}{l}2.587 \% \\
2.245 \% \\
(0.233)\end{array}$ \\
\hline $\begin{array}{l}\text { DEBT_ASSETS_1 }=1 \\
\text { DEBT_ASSETS_1 }_{-}=0 \\
p \text {-value }^{\mathrm{a}}\end{array}$ & $\begin{array}{l}1.170 \% \\
2.026 \% \\
(0.000)\end{array}$ & $\begin{array}{l}0.996 \% \\
2.026 \% \\
(0.000)\end{array}$ & $\begin{array}{l}2.945 \% \\
3.612 \% \\
(0.000)\end{array}$ \\
\hline
\end{tabular}

Notes: Table 3 shows the probabilities of the presence of banks as one of the largest shareholders contingent on different variables. ROA 1 measures the return on assets lagged by one period. ROA $1=1(0)$ means that ROA_1 is above (below) the mean value of that variable for the corresponding sector and year. DEBT_ASSETS is defined as a firm's total debt to total assets. DEBT_ASSETS_1 is the variable DEBT_ASSETS lagged by one period. DEBT ASSET $1=1(0)$ means that DEBT $\bar{A}$ SSET 1 is above (below) the mean value of that variable for the corresponding sector and year. The remaining variables are defined in Table 1.

${ }^{\mathrm{a}}$ The $p$-values of the Mann-Whitney tests are given in parentheses.

the emergence of a bank as one of the two largest blockholders on a firm's ROA, and on blockholders' stake (OWN2 and OWNALL variables). In those periods when there is such a change, one of the previous five 'transitional' dummies changes from a value of zero to a value of one.

We adopt in both specifications those control variables which are standard in this literature (Morck et al., 1988; Demsetz and Villalonga, 2001). In particular, for estimations of OWN2 and OWNALL, we introduce the following controls; first, size measured as a firm's overall sales on a log scale (LSALES). Second, reputation, gauged through a firm's age (AGE). Third, we also incorporate a variable of financial structure (DEBT_ASSETS) that is defined as the ratio of a firm's total debt to total assets. Finally, we also introduce the aforementioned measure of a firm's returns (ROA), as well as temporal dummies $\left(\right.$ Dumy $\left._{T}\right)$ and sectoral dummies (1-digit SIC Dumy $)_{S}$. Thus, the specifications we carry out for OWN2 as well as for OWNALL are as follows:

$$
\begin{aligned}
O W N_{i t}= & \beta_{0}+\beta_{1} \mathrm{NBNB}_{-} \mathrm{BNB}_{i t}+\beta_{2} \mathrm{NBNB}_{-} \mathrm{NBB}_{i t} \\
& +\beta_{3} \mathrm{NBB}_{-} \mathrm{BB}+\beta_{4} \mathrm{BNB}_{-} \mathrm{BB}_{i t}+\beta_{5} \mathrm{NBB}_{-} \mathrm{BNB}_{i t} \\
& +\beta_{6} \text { ROA } A_{i t}+\beta_{7} L S A L E S_{i t}+\beta_{8} A G E_{i t} \\
& +\beta_{9} D E B T_{-} \text {ASSETS } \\
& +\sum_{s=1}^{9} \beta_{9+S} \text { Dumy } \\
& +\sum_{T=1}^{4} \beta_{18+T} \text { Dumy }_{T i t}+\eta_{i}+\varepsilon_{i t}
\end{aligned}
$$

where OWN denotes OWN2 in some specifications, and OWNALL in others. The error term, $\varepsilon_{i t}$, has a normal distribution with zero mean and a $\sigma^{2}$ variance. Variable $\eta_{i}$ accounts for the unobservable heterogeneity.

The second equation, which is linked to the previous one because it incorporates OWN2 or alternatively OWNALL as an independent variable, is intended to estimate the effect on a firm's returns when banks buy a significant stake in a firm. The equation we propose has the same controls as the previous specification as well as an additional one for identification purposes. Demsetz and Villalonga (2001) propose $R \& D$, defined as the ratio of $R \& D$ investments to total assets, as an explanatory variable of firm's performance. Summarizing, our second equation is

$$
\begin{aligned}
& R O A_{i t}=\gamma_{0}+\gamma_{1} \mathrm{NBNB}_{-} \mathrm{BNB}_{i t}+\gamma_{2} \mathrm{NBNB}_{-} \mathrm{NBB}_{i t} \\
& +\gamma_{3} \text { NBB_BB }+\gamma_{4} \mathrm{BNB}_{-} \mathrm{BB}_{i t} \\
& +\gamma_{5} \mathrm{NBB}_{-} \mathrm{BNB}_{i t}+\gamma_{6}\{O W N\}_{i t}+\gamma_{7} L S A L E S_{i t} \\
& +\gamma_{8} A G E_{i t}+\gamma_{9} R \& D_{i t}+\gamma_{10} D E B T_{-} A S S E T S_{i t} \\
& +\sum_{s=1}^{9} \gamma_{10+S} \text { Dumy }_{S i t}+\sum_{T=1}^{4} \gamma_{19+T} \text { Dumy }_{T i t} \\
& +\eta_{i}^{\prime}+\varepsilon_{i t}^{\prime}
\end{aligned}
$$

where $\varepsilon_{i t}^{\prime}$ is the error term which has a normal distribution with zero mean and a $\sigma^{\prime 2}$ variance. Variable $\eta_{i}^{\prime}$ accounts for the unobservable heterogeneity. 
When estimating both equations we have to take into consideration the existence of two endogeneity problems. First, the unobservable heterogeneity $\left(\eta_{i}, \eta_{i}^{\prime}\right)$ may be correlated with some independent variables. The second endogeneity problem is linked to the possibility that the largest blockholders' stakes have an effect on performance in specification (1). This would generate biased results in such specifications. Also, it may be the case that in specification (2) a firm's ROA drives blockholders to change their stakes in a firm. In that case, the estimation of a firm's returns would also be biased. In order to tackle both endogeneity problems, we perform system Generalized Method of Moment (GMM) estimations (Arellano and Bond, 1991) following a two-stage process. ${ }^{11}$ In the first stage, we conduct a system GMM estimation of both specifications, using as instruments of the 'transitional dummies' and the potential endogenous variables (ROA and OWN), these variables lagged by different periods as well as the remaining predetermined variables (control variables). In the second stage, we repeat the GMM estimations and, apart from the lagged transitional dummies as instruments, we instrument ROA in specification (1) and OWN in specification (2), using the error term that is found in the estimations of the first stage. Note that this error term in specification (1) is correlated with OWN but it is not correlated with ROA. Thus, it is a good instrument of OWN in specification (2). In the same vein, the error term of specification (2) is correlated with ROA but it is not correlated with OWN. Thus, it is a good instrument of ROA in specification (1). ${ }^{12}$

\section{Results}

The results of Equation 1 are presented in Table 4, while those of Equation 2 are shown in Table 5. ${ }^{13}$

Table 4 shows that the emergence of a bank as one of the largest blockholders leads to a reduction in the overall blockholders' stake, as well as in that of the two largest blockholders, whenever the other blockholder is also a bank (negative coefficients of NBB_BB as well as BNB_BB). ${ }^{14}$ This conforms to Hypothesis 1, concerning the stake variable. Remarkably, the coefficient is more negative when a bank becomes the largest blockholder $\left(\mathrm{NBB} \_\mathrm{BB}=1\right)$ instead of the second largest one $(\mathrm{BNB} B \mathrm{BB}=1)$. This significant differential negative effect when a bank acquires the largest stake also holds when the second largest is not a bank (heterogeneous structures). In particular, the coefficient of NBNB_BNB is more negative (see columns 1 and 3) compared with that of NBNB_NBB (a bank becomes the second-largest blockholder of a firm that has a nonbank as the largest blockholder). This conforms to Hypothesis 2, for the stake variable. Also, columns 2 and 4 reveal that the status of a nonlending bank generates

${ }^{11}$ System GMM differs from difference GMM as the former not only uses information of the equations in differences, but also incorporates the information of the equation in levels. In particular, following the description given for xtabond 2 command of Stata program, departing from the model:

y_it $=x_{-}$it $* b_{-} 1+w_{-}$it $* b_{-} 2+u_{-}$it $\mathrm{i}=1, \ldots, \mathrm{N} ; \mathrm{t}=1, \ldots, \mathrm{T}$

$\mathrm{u} \_$it $=\mathrm{v} \_\mathrm{i}=\mathrm{e} \_$it,

where: $x \_$it is a vector of strictly exogenous covariates; w_it is a vector of predetermined covariates (which may include lags of y) and endogenous covariates, all of which may be correlated with the v_I (Predetermined variables are correlated with past errors. Endogenous variables are correlated with past and present errors.); b 1 and b 2 are vectors of parameters to be estimated; v_i are unobserved group-level effects; e_it is the observation-specific error term; and $E\left[v_{-} i\right]=E\left[e_{-} i t\right]=0$, $\mathrm{E}\left[\mathrm{v}_{-} \mathrm{i}{ }^{\mathrm{e}} \mathrm{e} \_\mathrm{it}\right]=\overline{0}$, and $\mathrm{E}\left[\mathrm{e} \_\mathrm{it} *{ }_{\mathrm{e}} \mathrm{is}\right]=0$ for each $\mathrm{i}, \mathrm{t}, \mathrm{s}, \mathrm{t}<>\overline{\mathrm{s}}$. The difference GMM version transforms the equation in differences in order to remove the $v_{i}$, thus eliminating a potential source of omitted variable bias in estimation. (However, in first differences, predetermined variables become endogenous.) Arellano and Bond (1991) developed a GMM estimator that treats the model as a system of equations, one for each time period. The equations differ only in their instrument/moment condition sets. The predetermined and endogenous variables in first differences are instrumented with suitable lags of their own levels. Strictly exogenous regressors, as well as any other instruments, enter the instrument matrix in the conventional instrumental variables fashion: in first differences, with one column per instrument. A problem with difference GMM estimator is that lagged levels are often poor instruments for first differences, especially for variables that are close to a random walk. System GMM overcomes this problem by adding the original equations in levels to the system. Then, additional moment conditions could be brought to bear to increase efficiency. In these equations, predetermined and endogenous variables in levels are instrumented with suitable lags of their own first differences.

${ }^{12}$ We have also conducted a simultaneous equation estimation (Three-Stage Least Squares (3SLS) estimation) and the results found remain qualitatively the same.

${ }^{13}$ We have computed the Variation Inflation Factor (VIF) in all estimations, and for all coefficients the VIF factor is lower than 5, which is well below the threshold of 20 that is considered as a signal of multicollinearity problems. Additionally the Belsley et al. test (1980) rejects such a multicollinearity problem.

${ }^{14}$ An alternative interpretation of the reduction in the stake in the hands of the largest shareholders may be due to banks preference for investing in large companies with more diluted ownership. However, note that the estimation technique that we have used compares the controlling stake of a particular firm before and after banks change their stakes. 
Table 4. Effects on blockholders' stake

\begin{tabular}{|c|c|c|c|c|}
\hline Dependent variable & OWN2 & & OWNALL & \\
\hline NBNB_BNB & $\begin{array}{r}-10.183^{*} \\
(6.372)\end{array}$ & $\begin{array}{l}11.900 \\
(8.230)\end{array}$ & $\begin{array}{r}-15.58 * * \\
(8.705)\end{array}$ & $\begin{array}{l}15.822^{* *} \\
(3.848)\end{array}$ \\
\hline NLNBNB_BNB & & $\begin{array}{c}-33.50 * * * \\
(9.563)\end{array}$ & & $\begin{array}{c}-41.791 * * * \\
(4.507)\end{array}$ \\
\hline NBNB_NBB & $\begin{array}{l}-9.271 * * * \\
(2.631)\end{array}$ & $\begin{array}{c}-18.150^{* * * *} \\
(6.625)\end{array}$ & $\begin{array}{c}-4.164 \\
(9.488)\end{array}$ & $\begin{array}{r}-12.422 * \\
(7.636)\end{array}$ \\
\hline NBB_BB & $\begin{array}{c}-22.270^{* * * *} \\
(2.898)\end{array}$ & $\begin{array}{c}-21.23^{* * * *} \\
(3.256)\end{array}$ & $\begin{array}{c}-26.710^{* * * *} \\
(3.373)\end{array}$ & $\begin{array}{c}-40.815^{* * *} * \\
(6.447)\end{array}$ \\
\hline BNB_BB & $\begin{array}{c}-12.039 * * * \\
(1.251)\end{array}$ & $\begin{array}{c}-11.90 * * * \\
(1.100)\end{array}$ & $\begin{array}{c}-11.150 * * * \\
(1.339)\end{array}$ & $\begin{array}{c}-11.207 * * * \\
(4.417)\end{array}$ \\
\hline NBB_BNB & $\begin{array}{c}-10.961^{* * * *} \\
(1.890)\end{array}$ & $\begin{array}{c}-7.531^{* *} \\
(3.570)\end{array}$ & $\begin{array}{c}-19.420 * * * \\
(3.803)\end{array}$ & $\begin{array}{r}-14.812 \\
(5.698)\end{array}$ \\
\hline $\mathrm{ROA}$ & $\begin{array}{l}24.721 * * \\
(1.217)\end{array}$ & $\begin{array}{c}27.83^{* *} \\
(14.220)\end{array}$ & $\begin{array}{l}-2.870 \\
(16.360)\end{array}$ & $\begin{array}{c}2.201 \\
(12.465)\end{array}$ \\
\hline LSALES & $\begin{array}{c}-0.443^{*} \\
(0.266)\end{array}$ & $\begin{array}{c}-0.334 \\
(0.272)\end{array}$ & $\begin{array}{c}-0.772 * * \\
(0.321)\end{array}$ & $\begin{array}{c}-0.625^{* *} \\
(0.331)\end{array}$ \\
\hline AGE & $\begin{array}{l}-0.292^{* * *} \\
(0.052)\end{array}$ & $\begin{array}{l}-0.301 * * * \\
(0.053)\end{array}$ & $\begin{array}{c}-0.387^{* * *} \\
(0.063)\end{array}$ & $\begin{array}{l}-0.327 * * * \\
(0.064)\end{array}$ \\
\hline DEBT_ASSETS & $\begin{array}{c}4.570 \\
(3.538)\end{array}$ & $\begin{array}{l}52.51 \\
(3.669)\end{array}$ & $\begin{array}{c}2.614 \\
(4.331)\end{array}$ & $\begin{array}{c}2.784 \\
(4.182)\end{array}$ \\
\hline CONSTANT & $\begin{array}{l}56.44 * * * \\
(8.376)\end{array}$ & $\begin{array}{l}59.14 * * * \\
(4.289)\end{array}$ & $\begin{array}{l}90.040 * * * \\
(5.326)\end{array}$ & $\begin{array}{l}88.760 * * * \\
(8.637)\end{array}$ \\
\hline Fitness of the model & $\begin{array}{l}54.790 \\
(0.000)\end{array}$ & $\begin{array}{r}102.630 \\
(0.000)\end{array}$ & $\begin{array}{l}93.990 \\
(0.000)\end{array}$ & $\begin{array}{l}127.46 \\
(0.000)\end{array}$ \\
\hline Hansen test & $\begin{array}{c}7.180 \\
(0.618)\end{array}$ & $\begin{array}{l}14.000 \\
(0.450)\end{array}$ & $\begin{array}{l}21.690 \\
(0.150)\end{array}$ & $\begin{array}{l}14.640 \\
(0.199)\end{array}$ \\
\hline $\mathrm{AR}(2)$ test & $\begin{array}{c}0.610 \\
(0.540)\end{array}$ & $\begin{array}{c}1.130 \\
(0.257)\end{array}$ & $\begin{array}{r}-1.530 \\
(0.127)\end{array}$ & $\begin{array}{l}-1.13 \\
(0.257)\end{array}$ \\
\hline Observations & 4083 & 4083 & 4083 & 4083 \\
\hline
\end{tabular}

Notes: Table 4 reports the effects on ownership concentration caused by changes in a firm's ownership structure associated with the presence of banks as the two main shareholders. See Table 1 for the definition of variables. All are GMM estimations; we take as instruments of the transitional dummies, the set of these variables as well as the predetermined control variables lagged by one or further periods. ROA is instrumented using the error term of the specification of ROA in Table 5 as described in the main text. $F$-test for the fitness of the model tests. The Hansen test reports the $J$-statistic ( $p$-values reported in parentheses), which is distributed as chi-squared under the null hypothesis of instruments validity (no correlation with the error term). The $\mathrm{AR}(2)$ is a test for a second-order serial correlation in the residuals which is distributed as $N(0,1)$ under the null hypothesis of no serial correlation. SDs are given in parentheses.

$* * *, * *$ and $*$ denote $p$-values $0.01,0.05$ and 0.10 , respectively.

a further reduction in blockholders' stakes, a result that suggests further expropriating intentions by nonlending banks rather than for lending ones (this is shown in the negative and significant $1 \%$ coefficient of NLNBNB_BNB). ${ }^{15}$ Finally, it is worth emphasizing, once we compare the coefficients of NBB_BB with that of NBNB_BNB, that the entrance of a bank as the largest shareholder has more negative effects on the stake when it is accompanied by another bank, than with other type of blockholder. This reinforces the idea that it is particularly damaging for blockholders interests to have the combination of a bank with large power (leading effect) accompanied with other banks (homogeneous effect).

Remarkably, the results found hold for OWN2 as well as for OWNALL. This means that expropriation affects both the controlling and noncontrolling blockholders. The former reduce their stake as a way of minimizing expropriating costs. The latter disinvest drastically in a firm that pursues the private objectives of controlling blockholders.

Concerning the relationship between ownership structure and performance, the results for the

\footnotetext{
${ }^{15}$ As in Table 5, we report only the coefficient of the variables that are the result of crossing the dummy NL with the transitional dummy NBNB_BNB, given that for the other transitional dummies, these variables fall into two categories: their coefficients are not significant or they are dropped due to multicollinearity problems.
} 
Table 5. Effects on performance

\begin{tabular}{|c|c|c|c|c|c|c|}
\hline Dependent variable & ROA & & ROA & & ROA1 & \\
\hline NBNB_BNB & $\begin{array}{r}-1.870 \\
(2.584)\end{array}$ & $\begin{array}{c}1.158 \\
(2.113)\end{array}$ & $\begin{array}{c}-0.632 \\
(2.371)\end{array}$ & $\begin{array}{c}1.931 \\
(2.902)\end{array}$ & $\begin{array}{c}-0.018 \\
(0.086)\end{array}$ & $\begin{array}{r}-0.016 \\
(0.085)\end{array}$ \\
\hline NLNBNB_BNB & & $\begin{array}{c}-10.070^{* *} \\
(5.237)\end{array}$ & & $\begin{array}{c}-19.144^{* * * *} \\
(7.357)\end{array}$ & & \\
\hline NBNB_NBB & $\begin{array}{c}0.752 \\
(1.140)\end{array}$ & $\begin{array}{c}-0.994 \\
(1.139)\end{array}$ & $\begin{array}{c}0.393 \\
(0.957)\end{array}$ & $\begin{array}{c}-1.786 \\
(1.972)\end{array}$ & $\begin{array}{c}-0.007 \\
(0.019)\end{array}$ & $\begin{array}{c}-0.004 \\
(0.019)\end{array}$ \\
\hline NBB_BB & $\begin{array}{c}-8.686^{* * *} \\
(1.650)\end{array}$ & $\begin{array}{c}-6.532 * * * \\
(1.421)\end{array}$ & $\begin{array}{c}-5.643^{* *} \\
(1.885)\end{array}$ & $\begin{array}{c}-3.943^{* *} \\
(2.162)\end{array}$ & $\begin{array}{c}-0.121^{* *} \\
(0.056)\end{array}$ & $\begin{array}{c}-0.112^{* *} \\
(0.054)\end{array}$ \\
\hline BNB_BB & $\begin{array}{c}-2.555 \\
(3.557)\end{array}$ & $\begin{array}{c}-0.007 \\
(2.384)\end{array}$ & $\begin{array}{c}-1.156 \\
(3.162)\end{array}$ & $\begin{array}{c}-1.755 \\
(3.593)\end{array}$ & $\begin{array}{c}7.752 \\
(4.875)\end{array}$ & $\begin{array}{c}7.070 \\
(4.534)\end{array}$ \\
\hline NBB_BNB & $\begin{array}{c}3.799 \\
(2.184)\end{array}$ & $\begin{array}{c}1.658 \\
(1.728)\end{array}$ & $\begin{array}{c}3.754 \\
(2.017)\end{array}$ & $\begin{array}{c}2.432 \\
(2.924)\end{array}$ & $\begin{array}{c}-0.036 \\
(0.026)\end{array}$ & $\begin{array}{c}-0.034 \\
(0.026)\end{array}$ \\
\hline OWN2 & $\begin{array}{c}-0.001 * * * \\
(0.000)\end{array}$ & $\begin{array}{c}-0.000^{* * *} \\
(0.000)\end{array}$ & & & $\begin{array}{c}-0.000 \\
(0.000)\end{array}$ & \\
\hline OWNALL & & & $\begin{array}{r}-0.000 \\
(0.000)\end{array}$ & $\begin{array}{r}-0.000 \\
(0.000)\end{array}$ & & $\begin{array}{c}0.000 \\
(0.000)\end{array}$ \\
\hline LSALES & $\begin{array}{c}0.002 \\
(0.008)\end{array}$ & $\begin{array}{c}0.007 \\
(0.008)\end{array}$ & $\begin{array}{c}0.005 \\
(0.009)\end{array}$ & $\begin{array}{c}0.004 \\
(0.007)\end{array}$ & $\begin{array}{l}0.005^{* *} \\
(0.002)\end{array}$ & $\begin{array}{l}0.005^{* *} \\
(0.002)\end{array}$ \\
\hline $\mathrm{AGE}$ & $\begin{array}{c}-0.000 \\
(0.000)\end{array}$ & $\begin{array}{r}-0.000 \\
(0.000)\end{array}$ & $\begin{array}{c}-0.000 \\
(0.000)\end{array}$ & $\begin{array}{c}-0.000 \\
(0.001)\end{array}$ & $\begin{array}{c}-0.000 \\
(0.000)\end{array}$ & $\begin{array}{c}-0.000 \\
(0.000)\end{array}$ \\
\hline $\mathrm{R} \& \mathrm{D}$ & $\begin{array}{c}-0.181 * * \\
(0.087)\end{array}$ & $\begin{array}{c}-0.111 \\
(0.096)\end{array}$ & $\begin{array}{c}-0.250 * * * \\
(0.081)\end{array}$ & $\begin{array}{c}-0.371^{* *} \\
(0.176)\end{array}$ & $\begin{array}{c}-0.090 * * * \\
(0.017)\end{array}$ & $\begin{array}{c}-0.094 * * * \\
(0.016)\end{array}$ \\
\hline DEBT_ASSET & $\begin{array}{c}-0.104^{* * *} \\
(0.028)\end{array}$ & $\begin{array}{c}-0.088^{* * *} * \\
(0.027)\end{array}$ & $\begin{array}{c}-0.097 * * * \\
(0.027)\end{array}$ & $\begin{array}{c}-0.056 \\
(0.044)\end{array}$ & $\begin{array}{c}-0.059 * * * \\
(0.016)\end{array}$ & $\begin{array}{c}-0.062 * * * \\
(0.015)\end{array}$ \\
\hline CONSTANT & $\begin{array}{c}0.088 \\
(0.126)\end{array}$ & $\begin{array}{c}0.014 \\
(0.118)\end{array}$ & $\begin{array}{c}0.171 \\
(0.117)\end{array}$ & $\begin{array}{c}0.0464 \\
(0.088)\end{array}$ & $\begin{array}{c}0.012 \\
(0.043)\end{array}$ & $\begin{array}{c}0.011 \\
(0.037)\end{array}$ \\
\hline Fitness of the model & $\begin{array}{c}38.860 \\
(0.000)\end{array}$ & $\begin{array}{c}41.590 \\
(0.000)\end{array}$ & $\begin{array}{c}41.100 \\
(0.000)\end{array}$ & $\begin{array}{l}52.600 \\
(0.000)\end{array}$ & $\begin{array}{l}14.390 \\
(0.000)\end{array}$ & $\begin{array}{l}14.430 \\
(0.000)\end{array}$ \\
\hline Hansen test & $\begin{array}{l}11.970 \\
(0.287)\end{array}$ & $\begin{array}{l}12.780 \\
(0.236)\end{array}$ & $\begin{array}{c}5.630 \\
(0.776)\end{array}$ & $\begin{array}{c}3.890 \\
(0.793)\end{array}$ & $\begin{array}{c}6.750 \\
(0.564)\end{array}$ & $\begin{array}{c}6.850 \\
(0.552)\end{array}$ \\
\hline AR(2) test & $\begin{array}{c}1.550 \\
(0.122)\end{array}$ & $\begin{array}{c}1.650 \\
(0.100)\end{array}$ & $\begin{array}{c}1.560 \\
(0.119)\end{array}$ & $\begin{array}{c}0.090 \\
(0.925)\end{array}$ & $\begin{array}{c}1.340 \\
(0.181)\end{array}$ & $\begin{array}{c}1.310 \\
(0.190)\end{array}$ \\
\hline Observations & 2838 & 2838 & 2838 & 2838 & 2362 & 2362 \\
\hline
\end{tabular}

Notes: Table 5 reports the effects on returns caused by changes in a firm's ownership structures associated with the presence of banks as the two main shareholders. See Table 1 for the definition of variables. All are GMM estimations; we take as instruments of the transitional dummies, the set of these variables as well as the predetermined control variables lagged by one or further periods. OWN2 and OWNALL are instrumented using the error term of their corresponding specification shown in Table 4 as described in the main text. Columns 1-4 report the results for ROA, while in columns 5 and 6 the dependent variable ROA is lead by one period (ROA1).

$F$-test for the fitness of the model tests. The Hansen test reports the $J=$ statistic ( $p$-values reported in parentheses), which is distributed as chi-squared under the null hypothesis of instruments validity (no correlation with the error term). The AR(2) is a test for a second-order serial correlation in the residuals which is distributed as $N(0,1)$ under the null hypothesis of no serial correlation. SDs are given in parentheses.

$* * *, * *$ and $*$ denote $p$-values $0.01,0.05$ and 0.10 , respectively.

specification of OWN2 confirm that firms adjust their ownership structure in response to their results. Our results, however, are less clear than those of Demsetz and Villalonga (2001), because ROA is only significant for the specification of OWN2. We can argue that Demsetz and Villalonga's study focuses on US-listed companies where costs to conveniently change a firm's ownership structure are low. In our database, there are only 133 firms $(3 \%$ of the original sample) listed on the stock market, which hinders changes in the ownership structure as time goes by.
Finally, control variables show that older and larger firms have more 'diluted' ownership. It is quite natural that a firm is initially owned by just a few shareholders and that these dilute their initial ownership with time.

The estimations of ROA are displayed in Table 5. In columns 1, 2 and 5, we use the variable OWN2 as proxy for blockholders' stake, while in columns 3 , 4 and 6 , we use OWNALL. In both cases, as we have explained in the methodological section, we instrument such variables through the error terms derived from the corresponding specifications 
of ownership in Table 4. Finally, in columns 5 and 6 , we show the estimations for columns 1 and 3, but leading the dependent variable by one period.

The results in Table 5 can be summarized as follows:

(1) There is a negative effect on a firm's returns when a bank buys the largest stake in a firm that already has another bank as the second largest shareholder $\left(\mathrm{NBB} \_\mathrm{BB}=1\right)$. This means that it is harmful for a firm when the emergence of a bank represents a change from a heterogeneous structure $(\mathrm{NBB}=1)$ to a homogeneous one $(\mathrm{BB}=1)$, especially when a bank holds the largest stake. This supports Hypothesis 1. Also, when we compare the coefficient of NBB_BB with that of NBNB_BNB in columns 1 and 3, we do find that the latter is negative, but not significant and it is only significant for nonlending banks as shown in columns 2 and 4 . Thus, we can state that a bank, on becoming the largest blockholder, has a negative impact on a firm's returns but only when accompanied by other banks or when it is a nonlending bank. Hence, the degree of homogeneity in the type of coalitions that banks can form in order to control the firm (homogeneous effect) has a relevant impact on a firm's returns when the largest blockholder is a bank (leading effect). This behaviour conforms to Hypothesis $1 .{ }^{16}$ However, according to such hypothesis, we also expect a negative sign for variable BNB_BB. We may argue that a firm with a blockholder structure BNB suffers expropriation from its controlling bank in such a way that the emergence of a second bank has only marginal negative effects on ROA.

(2) In heterogeneous structures (bank with nonbank), the emergence of a blockholder bank has a negative effect on returns when it holds the largest stake (NBNB_BNB=1) and is not a lending bank. This result provides partial support to Hypothesis 2.

(3) Concerning control variables, we find the following results. First, size has a positive effect on ROA. Second, leverage has a negative effect on ROA. Investment inefficiencies like debt overhang (Myers, 1977) may explain this negative outcome. ${ }^{17}$ Finally, R\&D, as a proxy of growth opportunities has a null or negative impact on ROA. This is a standard result when we use accounting measures to capture the profitability (Hitt et al., 1997). This result does not hold when we use market measures (Table 6).

\section{Robustness Analysis: Market Data}

Another way to extend our analysis is by focusing on listed firms. This allows us to use market measures of a firm's results, instead of accounting measures. In particular, we measure market performance through the market-to-book ratio as an approximation of Tobin's Q. We are conscious that the number of observations in all of these estimations is limited, so the results obtained must be analysed with some caution.

Table 6 shows the results for the estimation of the determinants of the stake of blockholders as well as that of a firm's performance. Also, we use the same two-stage process, described in the methodology, to tackle potential endogeneity issues. In columns 1 and 2 we show the results for the specifications of OWN2 and OWNALL, while in columns 3 and 4, we show the results for the specification of Tobin's Q. In columns 5 and 6 , we replicate specifications of columns 3 and 4 but using ROA as the dependent variable.

The analysis of OWN2 and OWNALL (columns 1 and 2) reveals that there is a decrease in blockholders' stake when a bank becomes the largest shareholder and the second largest shareholder is another bank. Note that for such a scenario we have also found the most significant effects on blockholders' stake for the overall sample (Table 4). Consistently, the analysis of performance shows that independently of whether we use market measures of performance (columns 3 and 4) or accounting ones (columns 5 and 6), the only variable that affects performance negatively is NBB_BB. Thus, for listed firms we only find a

\footnotetext{
${ }^{16}$ In Table 5 (columns 5 and 6), we present the results of leading the variable of performance by one period and, although still significant, the coefficients capturing the impact of changes of ownership in performance are one order of magnitude lower than those capturing the contemporaneous relationship. Such evidence indicates that firms adjust their ownership structure, although imperfectly, and there is some persistence effect of changes in the ownership structure on a firm's performance.

${ }^{17}$ Our result of a negative effect is consistent with the existence of high levels of leverage in Spanish firms in which the negative overhang problems outweigh the positive ones linked to tax benefits as well as reduction in agency problems due to a reduction in cash-flows (Jensen, 1986; Del Brio et al., 2003). Moreover, when we focus on listed firms (Table 6), debt plays a positive role in performance, which conforms to De Andrés et al. (2005) for a sample of 101 listed Spanish firms for the period 1991 to 1995.
} 
Table 6. Effects on blockholders' stake and performance (listed firms)

\begin{tabular}{|c|c|c|c|c|c|c|}
\hline & OWN2 & OWNALL & TOBIN_Q & & $\mathrm{ROA}$ & \\
\hline NBNB_BNB & $\begin{array}{l}-1.495 \\
(19.280)\end{array}$ & $\begin{array}{c}5.470 \\
(35.890)\end{array}$ & $\begin{array}{c}15.320 \\
(22.529)\end{array}$ & $\begin{array}{c}13.470 \\
(15.754)\end{array}$ & $\begin{array}{r}-0.075 \\
(0.103)\end{array}$ & $\begin{array}{c}0.024 \\
(0.048)\end{array}$ \\
\hline NBNB_NBB & $\begin{array}{l}-4.494 \\
(13.720)\end{array}$ & $\begin{array}{c}17.800 \\
(17.200)\end{array}$ & $\begin{array}{l}-6.290 \\
(28.870)\end{array}$ & $\begin{array}{c}5.682 \\
(10.773)\end{array}$ & $\begin{array}{c}0.234 \\
(0.314)\end{array}$ & $\begin{array}{c}-0.025 \\
(0.045)\end{array}$ \\
\hline NBB_BB & $\begin{array}{c}-38.640 * * * \\
(8.600)\end{array}$ & $\begin{array}{c}-38.170 * * * \\
(11.910)\end{array}$ & $\begin{array}{c}-8.221 * * \\
(3.900)\end{array}$ & $\begin{array}{c}-9.257^{* * *} \\
(3.449)\end{array}$ & $\begin{array}{r}-0.885^{*} \\
(0.552)\end{array}$ & $\begin{array}{c}-0.075^{* *} \\
(0.036)\end{array}$ \\
\hline NBB_BNB & $\begin{array}{c}-24.010 \\
(39.160)\end{array}$ & $\begin{array}{c}12.060 \\
(67.300)\end{array}$ & $\begin{array}{l}25.600 * * \\
(10.770)\end{array}$ & $\begin{array}{l}12.653^{* * *} \\
(3.589)\end{array}$ & $\begin{array}{l}0.253^{* * *} * \\
(0.074)\end{array}$ & $\begin{array}{l}0.126^{* * *} \\
(0.045)\end{array}$ \\
\hline TOBIN_Q & $\begin{array}{c}-0.081 \\
(0.499)\end{array}$ & $\begin{array}{r}-1.367^{*} \\
(0.773)\end{array}$ & & & & \\
\hline OWN2 & & & $\begin{array}{c}0.000 \\
(0.049)\end{array}$ & & $\begin{array}{c}-0.001 \\
(0.000)\end{array}$ & \\
\hline OWNALL & & & & $\begin{array}{c}-0.044 \\
(0.047)\end{array}$ & & $\begin{array}{c}-0.000 \\
(0.000)\end{array}$ \\
\hline LSALES & $\begin{array}{c}1.766 \\
(1.187)\end{array}$ & $\begin{array}{c}-0.648 \\
(1.085)\end{array}$ & $\begin{array}{c}0.102 \\
(0.476)\end{array}$ & $\begin{array}{c}-0.053 \\
(0.291)\end{array}$ & $\begin{array}{c}0.003 \\
(0.005)\end{array}$ & $\begin{array}{c}0.003 \\
(0.002)\end{array}$ \\
\hline AGE & $\begin{array}{c}-0.123 \\
(0.082)\end{array}$ & $\begin{array}{c}-0.153 \\
(0.167)\end{array}$ & $\begin{array}{c}-0.003 \\
(0.030)\end{array}$ & $\begin{array}{c}0.019 \\
(0.024)\end{array}$ & $\begin{array}{r}-0.000 \\
(0.000)\end{array}$ & $\begin{array}{r}-0.000 \\
(0.000)\end{array}$ \\
\hline R\&D & & & $\begin{array}{l}-85.900 \\
(114.800)\end{array}$ & $\begin{array}{c}-14.262 \\
(52.042)\end{array}$ & $\begin{array}{c}0.383 \\
(2.161)\end{array}$ & $\begin{array}{c}-0.632 \\
(0.405)\end{array}$ \\
\hline DEBT_ASSET & $\begin{array}{c}4.188 \\
(15.100)\end{array}$ & $\begin{array}{c}12.290 \\
(30.430)\end{array}$ & $\begin{array}{c}12.660 \\
(16.100)\end{array}$ & $\begin{array}{c}9.183 \\
(13.800)\end{array}$ & $\begin{array}{c}0.096 \\
(0.446)\end{array}$ & $\begin{array}{l}0.375^{* *} \\
(0.113)\end{array}$ \\
\hline CONSTANT & $\begin{array}{c}1.663 \\
(18.390)\end{array}$ & $\begin{array}{l}-69.300 \\
(118.380)\end{array}$ & $\begin{array}{c}-3.350 \\
(8.088)\end{array}$ & $\begin{array}{c}-0.627 \\
(5.210)\end{array}$ & $\begin{array}{c}-0.021 \\
(0.075)\end{array}$ & $\begin{array}{c}0.009 \\
(0.045)\end{array}$ \\
\hline Fitness of the model & $\begin{array}{l}11.110 \\
(0.000)\end{array}$ & $\begin{array}{l}34.660 \\
(0.000)\end{array}$ & $\begin{array}{c}49.010 \\
(0.000)\end{array}$ & $\begin{array}{l}128.45 \\
(0.000)\end{array}$ & $\begin{array}{l}27.570 \\
(0.000)\end{array}$ & $\begin{array}{l}67.870 \\
(0.000)\end{array}$ \\
\hline Hansen test & $\begin{array}{c}4.910 \\
(0.980)\end{array}$ & $\begin{array}{c}3.910 \\
(0.990)\end{array}$ & $\begin{array}{c}8.230 \\
(0.600)\end{array}$ & $\begin{array}{c}6.500 \\
(0.591)\end{array}$ & $\begin{array}{c}0.370 \\
(0.990)\end{array}$ & $\begin{array}{c}7.150 \\
(0.950)\end{array}$ \\
\hline $\mathrm{AR}(2)$ test & $\begin{array}{c}0.510 \\
(0.612)\end{array}$ & $\begin{array}{r}-0.550 \\
(0.585)\end{array}$ & $\begin{array}{r}-1.520 \\
(0.129)\end{array}$ & $\begin{array}{r}-1.410 \\
(0.159)\end{array}$ & $\begin{array}{c}1.130 \\
(0.250)\end{array}$ & $\begin{array}{c}0.260 \\
(0.797)\end{array}$ \\
\hline Observations & 166 & 166 & 166 & 166 & 166 & 166 \\
\hline
\end{tabular}

Notes: Table 6 shows, for listed firms, the effects on blockholders stake (columns 1 and 2), on market performance (columns 3 and 4) and on accounting performance (columns 5 and 6) due to changes in ownership structure associated with the presence of banks as the two main shareholders. See Table 1 for the definition of variables. All are GMM estimations; we take as instruments of the transitional dummies, the set of these variables as well as the predetermined control variables lagged by one or further periods. TOBIN_Q is instrumented using the error term of the corresponding specification in columns 3 and 4 , while OWN2 and OWNALL are instrumented using the error term of their corresponding specification in columns 1 and 2 as described in the main text.

$F$-test for the fitness of the model tests. The Hansen test reports the $J$-statistic ( $p$-values reported in parentheses), which is distributed as chi-squared under the null hypothesis of instruments validity (no correlation with the error term). The AR(2) is a test for a second-order serial correlation in the residuals which is distributed as $N(0,1)$ under the null hypothesis of no serial correlation. SDs are given in parentheses.

$* * *, * *$ and $*$ denote $p$-values $0.01,0.05$ and 0.10 , respectively.

negative effect on performance when the homogeneous effect (the two largest blockholders are banks) is combined with the leading effect (a bank acquires the largest stake). In the other scenarios, pressure from financial markets prevents expropriation by banks.

\section{Conclusions}

In this article, we study the impact on a firm's returns when a bank becomes a shareholder with a significant stake. We also look at the effect on blockholders' stakes.

We propose two hypotheses: first, there is a negative impact on a firm's returns, as well as on the blockholders' stake, when a bank becomes a large blockholder in a firm where other banks hold large stakes (homogenous effect). Second, in a firm without banks as large blockholders, the expropriating incentives of a bank that buys a significant stake is greater when this stake is the largest, as opposed to when it is not (leading effect).

Such results are confirmed in the empirical analysis that uses a panel data sample of Spanish firms, which 
is mainly composed of nonlisted firms, covering the period 1996 to 2000. More specifically, when a bank becomes the main blockholder in a firm that has another bank as the second-largest blockholder, there is a negative effect on a firm's returns. However, when a bank buys the largest stake of a firm that has a nonbank as the shareholder with the second largest stake, the effect on performance is negative only when the bank is a nonlending bank. Finally, in those situations where there is a decrease in a firm's returns, there is also a reduction in the stake of the largest blockholders. This is further evidence of banks' expropriating intentions mirrored by the reduction in their controlling stake as a way of minimizing expropriating costs.

The previous results confirm in essence our basic statement: a bank expropriates minority shareholders when it buys the largest stake and especially when it forms a coalition with other banks. However, the presence of a bank, per se, does necessarily generate negative returns in a firm where it has a holding.

Concerning possible limitations, a major drawback in our article is that it does not address the question of who the ultimate owner is, given the existence of indirect investment. We do not know whether a nonbank controlled firm is really controlled by a bank through indirect participation, or whether a bank-controlled firm is really a family firm. This provides a blurred image of what the real ownership structure is. We should mention that it is quite common, in Spain, to find indirect investments by banks in different firms. Remarkably, this feature reinforces our main result because we would expect even more expropriation in those cases with indirect participation by banks, as the expropriating cost would have been lower in comparison with the case of direct participations.

Some recommendations can be extracted from our article. First, firms should try to promote heterogeneous controlling blockholders. Second, they should try to avoid having several banks as controlling blockholders. Finally, it is better for banks to combine ownership and lending roles in order to reduce expropriation problems. The investigation of the long-term effect of such measures for performance and risks (Nguyen and Nivoix, 2009) will be the subject of future research.

\section{Acknowledgements}

The authors thank Jana Fidrmuc, J. Pindado, F.A. Cebenoyan and María Gutiérrez for their useful comments. This article has been presented at the EFMA Symposium of European Corporate
Governance 2005 in Leeds; at the European Financial Management Association Meeting 2004 in Basel and at the XI Annual Conference of Multinational Finance Society in Istanbul (2004). The financial support provided by the project of the Comunidad de Madrid (Grants \#2007/04083/001; \#2008/00037/001 and \#2009/00138/001), from the MEC (grant \#SEJ2006-09401) is gratefully acknowledged.

\section{References}

Arellano, M. and Bond, S. (1991) Some tests of specification for panel data: Monte Carlo evidence and an application to employment equations, Review of Economic Studies, 58, 277-97.

Banerjee, S., Leleux, B. and Vermaelen, T. (1997) Large shareholdings and corporate control: an analysis of stake purchases by French holding companies, European Financial Management Journal, 3, 23-43.

Becht, M. and Boehmer, E. (2002) Corporate control in Europe, in The Control of Corporate Europe (Eds) M. Becht and C. Mayer, Oxford University Press, Oxford, pp. 1-45.

Belsley, D., Kuh, E. and Welsch, R. (1980) Regression Diagnostics: Identifying Influential Data and Sources of Collinearity, Wiley, New York.

Bennedsen, M. and Wolfenzon, D. (2000) The balance of power in closely held corporations, Journal of Financial Economics, 58, 113-39.

Berglöf, E. (1990) Capital structure as a mechanism of control, a comparison of financial systems, in The Firm as a Nexus of Treaties (Ed.) M. Aoki, Sage Publications, London, pp. 237-61.

Bloch, F. and Hege, U. (2002) Multiple shareholders and control contests, Manuscript. Available at http//www.dcgn.dk/Conferences/2002/hege-2002.pdf (accessed 1 December 2009).

Boehmer, E. (2000) Business group, bank control and large shareholders, an analysis for German takeover, Journal of Financial Intermediation, 9, 117-48.

Cable, J. R. (1985) Capital market information and industrial performance: the role of West German banks, Economic Journal, 95, 118-32.

Chirinko, R. S. and Elston, J. A. (2006) Finance, control and profitability: the influence of German banks, Journal of Economic Behavior and Organization, 59, 69-88.

Crespí-Cladera, R. and Garcia-Cestona, M. A. (2002) Ownership and control of Spanish listed firms, in The Control of Corporate Europe (Eds) F. Barca and M. Becht, OUP, Oxford.

Crespí-Cladera, R., Garcia-Cestona, M. A. and Salas, V. (2004) Governance mechanisms in Spanish banks. Does ownership matter?, Journal of Banking and Finance, 28, 2311-30.

De Andrés, P., López, F. J. and Rodríguez, J. A. (2005) Financial decisions and growth opportunities: a Spanish firm's panel data analysis, Applied Financial Economics, 15, 391-407.

Degryse, H. and de Jong, A. (2006) Investment and internal finance: asymmetric information or managerial 
discretion?, International Journal of Industrial Organization, 24, 125-47.

Del Brio, E., De Miguel, A. and Pindado, J. (2003) Investment and firm value: an analysis using panel data, Applied Financial Economics, 13, 913-23.

Demsetz, K. and Lehn, K. (1985) The structure of corporate ownership, causes and consequences, Journal of Political Economy, 93, 1155-77.

Demsetz, K. and Villalonga, B. (2001) Ownership structure and corporate performance, Journal of Corporate Finance, 7, 209-33.

Edwards, J. and Fischer, K. (1994) Banks, Finance and Investment in Germany, Cambridge University Press, Cambridge.

Edwards, J. and Nibler, M. (2000) Corporate governance in Germany. The role of banks and ownership concentration, Economic Policy, A European Forum, 15, 237-60.

Faccio, M. and Lang, L. H. P. (2002) The ultimate ownership of Western European corporations, Journal of Financial Economics, 65, 365-95.

Goergen, M., Rennebog, L. and Correia, L. (2005) When do German firms change their dividends?, Journal of Corporate Finance, 11, 375-99.

Gomes, A. R. and Novaes, W. (2005) Sharing of control as a corporate governance mechanism, PIER Working Paper No. 01-029.

González, F. (2004) Do equity investments affect banks' profitability? Evidence from OECD countries, Applied Financial Economics, 14, 1111-24.

Gorton, G. and Schmid, F. A. (2000) Universal banking and the performance of German firms, Journal of Financial Economics, 95, 29-80.

Gorton, G. and Winton, A. (2003) Financial intermediation, in The Handbook of the Economics of Finance, Chap. 8 (Eds) G. M. Constantinides, M. Harris and R. Stulz, Elsevier, Amsterdam, pp. 431-552.

Granero, L. and Redondo, J. C. (2005) Competition, risk taking, and governance structures in retail banking, Applied Financial Economics Letters, 1, 37-40.

Guzmán, I. and Reverte, C. (2008) Productivity and efficiency change and shareholder value: evidence from Spanish banks, Applied Economics, 40, 2033-40.

Han, L., Storey, D. J. and Fraser, S. (2008) The concentration of creditors: evidence from small businesses, Applied Financial Economics, 18, 1647-56.

Hellwig, M. (1998) Banks, markets and the allocation of risk in an economy, Journal of Institutional and Theoretical Economics, 54, 328-45.

Hitt, M. A., Hoskisson, R. E. and Kim, H. (1997) International diversification: effects on innovation and firm performance in product-diversified firms, The Academy of Management Journal, 40, 767-98.

Hoshi, T. and Kashyap, A. (2001) Corporate Financing and Governance in Japan: The Road to the Future, MIT Press, Cambridge, MA.

Hoshi, T., Kashyap, A. and Scharfstein, D. (1990) The role of banks in reducing the costs of financial distress in Japan, Journal of Financial Economics, 27, 67-88.

Jensen, M. C. (1986) Agency costs of free cash flows, corporate finance, and takeovers, American Economic Review, 76, 323-39.

Kaplan, S. and Minton, B. (1994) Appointments of outsiders to Japanese boards: determinants and implications for managers, Journal of Financial Economics, 36, 225-58.
Kroszner, R. and Strahan, A. (2001) Bankers on boards: monitoring, conflicts of interests, and lender liability, Journal of Financial Economics, 62, 415-52.

Kumbhakar, S. C. and Lozano-Vivas, A. (2004) Does deregulation make markets more competitive? Evidence of mark-ups in Spanish savings banks, Applied Financial Economics, 14, 507-15.

La Porta, R., Lopez-de-Silanes, F. and Shleifer, A. (1999) Corporate ownership around the world, The Journal of Finance, 54, 471-517.

La Porta, R., Lopez-de-Silanes, F. and Zamarripa, G. (2003) Related lending, Quarterly Journal of Economics, 118, 231-68.

Lozano, A. (1998) Efficiency and technical change for Spanish banks, Applied Financial Economics, 8, 289-300.

Maury, B. and Pajuste, A. (2005) Multiple large shareholders and firm value, Journal of Banking and Finance, 29, 1813-35.

Morck, R. (2000) Concentrated Corporate Ownership, National Bureau of Economic Research, University of Chicago Press Ltd, London.

Morck, R., Nakamura, M. and Shivdasani, A. (2000) Banks, ownership structure, and firm value in Japan, Journal of Business, 73, 539-67.

Morck, R., Shleifer, A. and Vishny, R. (1988) Management ownership and market valuation, an empirical analysis, Journal of Financial Economics, 20, 292-315.

Myers, S. (1977) Determinants of corporate borrowing, Journal of Financial Economics, 5, 147-75.

Nguyen, P. and Nivoix, S. (2009) The effect of group affiliation on the risk-taking of Japanese firms, Applied Financial Economics, 19, 135-46.

Pagano, M. and Röell, A. (1998) The choice of stock ownership structure: agency costs, monitoring and the decision go public, Quarterly Journal of Economics, 113, $187-225$.

Prowse, S. (1992) The structure of corporate governance in Japan, Journal of Finance, 42, 1121-40.

Rajan, R. and Zingales, L. (2003) Banks and markets: the changing character of European firms, Working Paper No. 9595, National Bureau of Economic Research.

Santos, J. (1998) Banking and commerce: how does the United States compare to other countries?, Federal Reserve Bank of Cleveland Economic Review, 34, 14-26.

Santos, J. A. C. and Rumble, A. S. (2006) The American keiretsu and universal banks: investing, voting and sitting on nonfinancials' corporate boards, Journal of Financial Economics, 80, 419-54.

Saunders, A. and Walter, I. (1994) Universal Banking in the US?, Oxford University Press, Oxford, UK.

Shleifer, A. and Vishny, R. (1986) Large shareholders and corporate control, Journal of Political Economy, 94, 461-88.

Winton, A. (2001) Institutional liquidity needs and the structure of monitored finance, Working Paper, University of Minnesota, Minneapolis, MN.

Zoido, M. E. (1998) Un estudio de las participaciones accionariales de los bancos en las empresas españolas, Investigaciones Económicas, 22, 427-67.

Zwiebel, J. (1995) Block investment and partial benefits of corporate control, Review of Economic Studies, 62, 161-85. 